\title{
Immunofluorescence Test on Schistosoma mansoni Worm Paraffin Sections (IgM-IFT) for the Study of Schistosomiasis Transmission in Campinas, São Paulo, Brazil
}

\author{
Virgília LC Lima/+ , Vânia MF Guercio*, Osias Rangel, Hermínia Y \\ Kanamura $^{* *}$, Luiz Cândido S Dias
}

\begin{abstract}
Superintendência de Controle de Endemias, Sucen, Rua São Carlos 546, 13035-420 Campinas, SP, Brasil
*Instituto Adolfo Lutz, Rua São Carlos 720, 13035-420 Campinas, SP, Brasil **Faculdade de Ciências

Farmacêuticas, Universidade de São Paulo, Av. Prof. Lineu Prestes 580 (Bloco 17), 05508-900 São Paulo, SP, Brasil ***Faculdade de Ciências Médicas, Universidade Estadual de Campinas, Caixa Postal 6111, 13083-970

Campinas, SP, Brasil
\end{abstract}

The detection of IgM antibodies for Schistosoma mansoni using gut-associated antigens (IgM-IFT) was compared to the parasitological Kato-Katz method for study of the transmission of schistosomiasis in an urban area in Campinas. About 400 schoolchildren whose ages ranged from 6 to 18 years, were observed for a period of two years. Blood samples on filter paper and fecal samples were collected, at intervals of six months. Serological (IgM-IFT) prevalence rates of 1.2\%, 4.3\%, 3.6\%, $2.9 \%$ and 3.4\% were obtained in five surveys carried out. S. mansoni eggs were detected in only one child out of the 225 children (0.4\%) who were submitted to the Kato-Katz method (three slides for each fecal sample) in the 1st survey. Sixty eight children who submitted five blood samples, one for each survey, were found IFT negative throughout the study. No child was found to be IFT positive in all five surveys, and only four children showed IFT positive results in at least four surveys. Seroconversion from IFT negative to positive was observed from the 1st to the 2nd survey in six chidren, from the 2 nd to the 3rd survey in three children, from the 3rd to the 4th survey in four children, and from the 4th to the 5th survey in two cases. However, confirmation of S. mansoni infection using the fecal examination was not possible in any of the cases. Also, in most of them the IFT result oscillated from negative to positive and vice versa. Our data implied that recent transmission of schistosomiasis in the study area was not possible.

Key words: Schistosoma mansoni - epidemiology - immunodiagnosis - seroconversion

Schistosomiasis is not noticed as a serious disease in the State of São Paulo, because most of the infected individuals have a small worm burden and the clinical manifestations are vague and nonspecific. These characteristics make the clinical and parasitological diagnosis of the disease difficult. Consequently, the control and eradication of the disease become hard. As a result, the population under the risk of infection does not worry about the disease. So, as a consequence, the expansion and urbanization of the disease have been intensified. The occurrence of schistosomiasis can be seen in the peri-urban areas of large cities (Silva 1983, 1992, Lima 1993). Fecal examination by Kato-Katz (Katz et al. 1972) technique is inefficient for detection of individuals with low worm burden, elimi-

${ }^{+}$Corresponding author. Fax: +55-19-272.9891. E-mail: sr05@ sucen.sp.gov.br

Received 4 May 1998

Accepted 31 August 1998 nating less than 100 eggs gram of feces (epg) (Barreto et al. 1990, De Vlas \& Gryseels 1992, Engels et al. 1996). The egg count of infected population in the endemic areas of São Paulo is usually less than 50 epg (Dias et al. 1992a). The techniques for detecting circulating antigens are also not sensitive enough in individuals with low infection (ElMorshedy et al. 1996, Hakangard et al. 1996). Therefore, the antibody detection techniques are certainly valuable for the improvement of schistosomiasis control in low endemic areas of São Paulo. In some regions of the state, we have found that higher prevalence indices were obtained by immunodiagnostic tests when compared to those obtained through the parasitological examination of the feces. This is due to the low sensitivity of the latter method. The diagnostic efficacy of fecal examination can be improved by repeating the exam in other samples (Dias et al. 1971, HoshinoShimizu et al. 1986, Bergquist 1992).

The Department of Health of the State of São Paulo Government began the control of schistoso- 
miasis in the state in 1968-1969, mainly by the use of selective chemotherapy and molluscicides (Cacesq 1973, Sucen 1982). The control program was based on the parasitological Kato-Katz technique as a single diagnostic method to select individuals for chemotherapy. These measures reduced the infection in the state (Marçal et al. 1991). But according to recent studies, transmission still occurs in many areas considered as of risk for schistosomiasis in São Paulo. Control programs have been developed in the following regions: Vale do Rio Paraíba do Sul, Vale do Rio Ribeira de Iguape, Baixada Santista, Litoral Sul, Vale do Paranapanema and the metropolitan regions of São Paulo and Campinas.

From 1981 to 1990 , after an initial reduction of cases in the region of Campinas, an increase in the number of autochthonous cases was detected, mainly due to the expansion of the transmission area. Schistosomiasis cases start to be found in municipalities where it was not notified before. Until 1980, transmission was detected in four municipalities of the region, but by the end of the decade it was reported in 17 of the 85 municipalities that constitute the Campinas region. In most cases, transmission occurred in the border of the cities (Lima 1993). The first autochthonous cases of schistosomiasis were found in 1960, in the municipality of Campinas, where the highest number of cases in the region has been notified in the last years. According to the available data, in this municipality, there is also no indication for increasing of the level of $S$. mansoni transmission in the former endemic foci, but expansion of the transmission area was observed (Lima 1993).

In this study, a group of schoolchildren residing in the urban area of the municipality of Campinas were submitted to the parasitological and serological surveys in order to evaluate the potential of the immunoflorescence test in detecting IgM antibodies (RIF-IgM), to be used in epidemiological studies and as an instrument to understand the transmission of schistosomiasis in Campinas.

\section{MATERIALS AND METHODS}

Description of the population and region studied - The municipality of Campinas has $1076 \mathrm{~km}^{2}$ and is $98 \mathrm{~km}$ from the capital of the State of São Paulo. It is highly industrialized and urbanized, and attracts the population from the countryside of the state. The climate is subtropical with hot and humid summers. It is intersected by waterways originating from the Piracicaba and Tiête rivers.

This study was carried out in Vila Costa e Silva, district of Barão Geraldo, in the municipality of Campinas. Until the beginning of the 1980s, Vila Costa e Silva and the neighboring areas had the highest number of autochthonous cases in the north part of the municipality. This was the area in the municipality of Campinas that presented the highest transmission levels. From 1979 to 1983, 141 autochthonous cases were reported in Vila Costa e Silva and the neighboring areas. After this period, a clear reduction in the number of reported cases was observed. From 1984 to 1997, only 40 autochthonous cases were reported in the locality. In a survey conducted in 1990 in the schools, no cases were detected. In this region, the intermediary host for S. mansoni is the Biomphalaria tenagophila (Lima 1993).

Fecal and blood samples of a group of children from a school located in Vila Costa e Silva were collected. Five surveys were conducted. The first survey was in October of 1992 and the fifth in October of 1994.

Immunofluorescent test (IFT) - IgM antibodies to $S$. mansoni gut antigens on Rossman's solution fixed adult worm paraffin sections were detected by IFT, according to the technique previously described (Silva et al. 1992). Several drops of capillary blood from a fingertip were collected from each individual onto a Whatman \#3 filter paper, dried at room temperature and stored in a plastic bag at $-20^{\circ} \mathrm{C}$. For the IFT, the dried blood spot discs were cut from the filter by a punch with $8 \mathrm{~mm}$ diameter. The paper discs were eluted in 120 ( 1 of $0.01 \mathrm{M}$ pH7.2 PBS (Phosphate buffer solution), incubating overnight at $4^{\circ} \mathrm{C}$. The serum dilution in each eluate after removal of the paper disc was estimated to be 1:16 (Ferreira \& Carvalho 1982). A commercial antihuman IgM fluorescent conjugate (Biolab, Rio de Janeiro, Brazil) was used according to the respective titers determined by block titration against known positive and negative standard serum samples. It was given as positive result only the reaction showing fluorescence on gut associated antigen, as described (Kanamura et al. 1991).

Fecal examination - In each survey, the KatoKatz technique (Katz et al. 1972) was performed on one fecal specimen from each schoolchild, with three slides for each sample.

Statistical analysis - Using the Epi-Info program, version 6.02, a data bank was organized for personal, clinical and laboratory data. The same program was used to analyze the results obtained for the five surveys (Dean et al. 1995).

\section{RESULTS}

Table I shows positivity indices obtained in the parasitological (Kato-Katz) and the serological (IFT-IgM) methods in five surveys conducted with a selected group of schoolchildren.

A complete serological follow-up, with five blood samples submitted to the IFT-IgM, was ob- 
tained for 71 schoolchildren. Of these, 68 children $(95.8 \%)$ revealed IFT-IgM negative results in all five surveys (Table II). Seroconversion from negative to positive was observed in 14 cases in successive surveys: from the 1 st to the 2 nd survey in six children, from the 2 nd to the 3 rd in three, from the 3 rd to the 4 th in four, and from the 4 th to the 5 th in two children; one of these last two cases also showed seroconversion from the 1 st to the 2 nd survey (Table III).

TABLE I

Prevalence of Schistosoma mansoni by the Kato-Katz parasitological and the IFT-IgM serological method in five surveys, conducted every six months on schoolchildren in the municipality of Campinas, São Paulo

\begin{tabular}{|c|c|c|c|c|c|c|}
\hline \multirow{3}{*}{ Survey } & \multicolumn{3}{|c|}{ Kato-Katz } & \multicolumn{3}{|c|}{ IFT-IgM } \\
\hline & \multirow{2}{*}{$\begin{array}{l}\text { Total } \\
(\mathrm{F} / \mathrm{M})\end{array}$} & \multicolumn{2}{|c|}{ Infected } & \multirow{2}{*}{$\begin{array}{l}\text { Total } \\
(\mathrm{F} / \mathrm{M})\end{array}$} & \multicolumn{2}{|c|}{ Infected } \\
\hline & & $\begin{array}{l}\text { No. } \\
(\mathrm{F} / \mathrm{M})\end{array}$ & $\%$ & & $\begin{array}{c}\text { No. } \\
(\mathrm{F} / \mathrm{M})\end{array}$ & $\%$ \\
\hline 2nd sem/92 & $\begin{array}{c}255 \\
(130 / 125)\end{array}$ & $\begin{array}{c}1 \\
(0 / 1)\end{array}$ & $\begin{array}{c}0.4 \\
(0.02-2.5)^{a}\end{array}$ & $\begin{array}{c}426 \\
(207 / 219)\end{array}$ & $\begin{array}{c}5 \\
(1 / 4)\end{array}$ & $\begin{array}{c}1.2 \\
(0.4-2.9)^{a}\end{array}$ \\
\hline 1 st sem/93 & $\begin{array}{c}177 \\
(86 / 91)\end{array}$ & 0 & $\begin{array}{c}0 \\
(0-2.6)\end{array}$ & $\begin{array}{c}485 \\
(219 / 266)\end{array}$ & $\begin{array}{c}21 \\
(4 / 17)\end{array}$ & $\begin{array}{c}4.3 \\
(2.8-6.6)\end{array}$ \\
\hline 2nd sem/93 & $\begin{array}{c}59 \\
(29 / 30)\end{array}$ & 0 & $\begin{array}{c}0 \\
(0-7.6)\end{array}$ & $\begin{array}{c}359 \\
(174 / 185)\end{array}$ & $\begin{array}{c}13 \\
(5 / 8)\end{array}$ & $\begin{array}{c}3.6 \\
(2.0-6.3)\end{array}$ \\
\hline 1 st sem/94 & $\begin{array}{c}51 \\
(26 / 25)\end{array}$ & 0 & $\begin{array}{c}0.4 \\
(0-8.7)\end{array}$ & $\begin{array}{c}383 \\
(169 / 214)\end{array}$ & $\begin{array}{c}11 \\
(2 / 9)\end{array}$ & $\begin{array}{c}2.9 \\
(1.5-5.2)\end{array}$ \\
\hline 2nd sem/94 & $\begin{array}{c}67 \\
(34 / 33)\end{array}$ & 0 & $\begin{array}{c}0 \\
(0-6.8)\end{array}$ & $\begin{array}{c}325 \\
(153 / 172)\end{array}$ & $\begin{array}{c}11 \\
(4 / 7)\end{array}$ & $\begin{array}{l}3.4 \\
(1.8-6.1)\end{array}$ \\
\hline
\end{tabular}

F: female, M: male; $a$ : (95\% confidence intervals).

\section{TABLE II}

Serological follow-up for schistosomiasis mansoni using IFT-IgM on blood samples of 71 school children taken every six months in five surveys in Campinas, São Paulo

\begin{tabular}{cccccc}
\hline \multirow{2}{*}{$\begin{array}{c}\text { No. of } \\
\text { children }\end{array}$} & \multicolumn{5}{c}{ IFT-IgM results in five surveys } \\
\cline { 2 - 6 } & 2nd sem/92 & 1st sem/93 & 2nd sem/93 & 1st sem/94 & 2nd sem/94 \\
\hline 69 & $\mathrm{~N}$ & $\mathrm{~N}$ & $\mathrm{~N}$ & $\mathrm{~N}$ & $\mathrm{~N}$ \\
0 & $\mathrm{P}$ & $\mathrm{P}$ & $\mathrm{P}$ & $\mathrm{P}$ & $\mathrm{P}$ \\
2 & $\mathrm{P}$ & $\mathrm{P}$ & $\mathrm{N}$ & $\mathrm{P}$ & $\mathrm{P}$ \\
1 & $\mathrm{~N}$ & $\mathrm{P}$ & $\mathrm{P}$ & $\mathrm{N}$ & $\mathrm{P}$ \\
\hline
\end{tabular}

TABLE III

IFT-IgM for schistosomiasis in seroconversion cases in five surveys, on schoolchidren in Campinas, São Paulo

\begin{tabular}{lccccc}
\hline & \multicolumn{5}{c}{ Results of IFT-IgM in each survey } \\
\cline { 2 - 6 } Case & 2nd sem/92 & 1st sem/93 & 2nd sem/93 & 1st sem/94 & 2nd sem/94 \\
\hline FSP & $\mathrm{N}$ & $\mathrm{P}$ & $\mathrm{P}$ & - & - \\
KRC & $\mathrm{N}$ & $\mathrm{P}$ & - & $\mathrm{P}$ & $\mathrm{P}$ \\
TAR & $\mathrm{N}$ & $\mathrm{P}$ & $\mathrm{P}$ & $\mathrm{N}$ & $\mathrm{P}$ \\
CFS & $\mathrm{N}$ & $\mathrm{P}$ & - & $\mathrm{P}$ & $\mathrm{P}$ \\
FLC & $\mathrm{N}$ & $\mathrm{P}$ & $\mathrm{P}$ & - & - \\
ESG & $\mathrm{N}$ & $\mathrm{P}$ & $\mathrm{N}$ & - & - \\
AB & $\mathrm{N}$ & $\mathrm{N}$ & $\mathrm{P}$ & - & - \\
NVS & - & $\mathrm{N}$ & $\mathrm{P}$ & $\mathrm{N}$ & - \\
GFS & - & $\mathrm{N}$ & $\mathrm{P}$ & - & - \\
RCBS & $\mathrm{P}$ & $\mathrm{P}$ & $\mathrm{N}$ & $\mathrm{P}$ & $\mathrm{P}$ \\
VJC & $\mathrm{P}$ & $\mathrm{P}$ & $\mathrm{N}$ & $\mathrm{P}$ & $\mathrm{P}$ \\
CST & $\mathrm{P}$ & $\mathrm{P}$ & $\mathrm{N}$ & $\mathrm{P}$ & - \\
GSP & - & $\mathrm{P}$ & $\mathrm{N}$ & $\mathrm{N}$ & - \\
CRF & - & $\mathrm{P}$ & $\mathrm{P}$ & $\mathrm{P}$ \\
\hline
\end{tabular}




\section{DISCUSSION}

Previous studies have demonstrated the high sensitivity level of IFT-IgM in diagnosing acute as well as chronic schistosomiasis, and its specificity in relation to clinically healthy individuals as well as to those with different parasitic infections (Kanamura et al. 1991, 1998a, Silva et al. 1992, Lima et al. 1996).

The positivity indices obtained in all of the five surveys were significantly higher by the IFT-IgM than by the Kato-Katz technique (Table I). This difference between serological and parasitological prevalence data, always higher for the former, have also been observed in various other epidemiological studies in which different methods were compared (Dias et al. 1971, 1992a, Kawazoe et al. 1981, Eltiro et al. 1992, Noya et al. 1992, 1995, Idris et al. 1994). However, the serological prevalence indices observed in the schoolchildren of Campinas, ranging from 1.2 to $4.3 \%$, are far lower than those normally found in other studies. These data reflect the parasitological prevalence obtained by the Kato-Katz method (Table I), and are in accordance with the historical aspects of schistosomiasis in the region being studied. The reduced number of autochthonous cases notified in the last few years, for the studied area, is already stressed. Although the percentage of serologically positive individuals is reduced, it is still significant when compared to the results of the fecal examination, which detected only one case. This could be due to various conditions: greater sensitivity of the serological method; failure of the parasitological method when the number of parasites is low; cross reactions with other parasites or free cercariae; remaining antibodies from past infections. These factors have to be thoroughly investigated so as to interpreting realistically the obtained results.

A seasonal transmission of schistosomiasis was detected when a serological follow-up study with the IFT-IgM was done in a group of schoolchildren of Itariri, Vale do Ribeira, another endemic area for schistosomiasis in São Paulo. Higher seroconversion levels were observed in surveys after summer in comparison to ones conducted after winter (Kanamura et al. 1998b). This seasonal transmission was not observed with the school children in Campinas (Tables II, III). This might indicate that the risk of infection with $S$. mansoni was low. In a few cases, seroconversion from negative to positive can be detected between two successive surveys, but this seroconversion can not be confirmed because oscillations in the IFT-IgM results or the failure follow-up. Oscillations in IFTIgM results from negative to positive and vice-versa were occasionally observed in some individuals with low level of antibodies. A low transmission level of $S$. mansoni in the studied region was also confirmed by the high percentage of individuals with negative serological results in all five surveys or at least in four of them. However, this does not mean that an epidemiological vigilance program for schistosomiasis is not necessary. It is very important because of the following factors: the presence of breeding of the $S$. mansoni intermediary snails; a constant pressure of infected individuals coming from other Brazilian states or from other schistosomisasis endemic regions of São Paulo and occurrence of sporadic autochthonous cases in the studied region. Undoubtedly the serological method would be more efficient than the parasitological method in low endemic areas.

Despite of the mentioned limitations, because of its high sensitivity in detecting schistosomiasis at a very early phase after infection, the IFT-IgM is certainly a valuable instrument to study the dynamics of S. mansoni transmission in low endemic areas. The IFT-IgM is useful for the identification of carriers, which can later be confirmed by exhaustive parasitological examinations, contributing towards an improvement of the schistosomiasis control for the region of Campinas.

\section{REFERENCES}

Barreto ML, Smith DH, Sleigh AC 1990. Implications of faecal egg count variation when using the KatoKatz method to assess Schistosoma mansoni infections. Trans R Soc Trop Med Hyg 84: 554-555.

Bergquist NR1992. Immunodiagnostic Approches in Schistosomiasis, John Wiley \& Sons, London, ??pp.

Cacesq - Campanha de Combate à Esquistossomose 1993. I Encontro Nacional sobre esquistossomose, São Paulo, Governo do Estado de São Paulo, Secretaria de Estado da Saúde.

Dean AG, Dean JA, Coulombier D, Brendel KA, Smith DC, Burton AH, Dicker RC, Sullivan KM, Fargan RF, Arner TG 1995. Epi Info, Version 6: a Word Processing, Database, and Statistics Program for Public Health on IBM-Compatible Microcomputers. Centers of Disease Control and Prevention, Atlanta, GA, U.S.A.

De Vlas SJ, Gryseels B 1992. Underestimation of Schistosoma mansoni prevalences. Parasitol Today 8: 274277.

Dias LCS, Camargo ME, Hoshino-Shimizu S, Ramos AS, Toledo Piza J, Silva LC 1971. Inquéritos populacionais de esquistossomose mansoni por técnicas sorológicas de imunofluorescência e de hemaglutinação. Rev Inst Med Trop São Paulo 13: 37-44.

Dias LCS, Kanamura HY, Hoshino-Shimizu S, Glasser CM, Carvalho JF, Silva LC 1992a. Field trials for immunodiagnosis with reference to Schistosoma mansoni, p. 39-47. In NR Bergquist, Immunodiagnostic Approches in Schistosomiasis, John Wiley \& Sons, London. 
Dias LCS, Marçal Jr O, Glasser CM, Kanamura HY, Hotta LK 1992. Control of schistosomiasis mansoni in a low transmission area (Controle da esquistossomose mansônica em área de baixa transmissão). Mem Inst Oswaldo Cruz 87 (Suppl. IV): 233-239.

El-Morshedy H, Kinosien B, Barakat R, Omer E, Khamis N, Deelder AM, Phillips M 1996. Circulating anodic antigen for detection of Schistosoma mansoni infection in Egyptian patients. Amer J Trop Med Hyg 54: 149-153.

Eltiro F, Ye-Ebiyo Y, Taylor MG 1992. Evaluation of an enzyme linked immunosorbent assay (ELISA) using Schistosoma mansoni soluble egg antigen as a diagnostic tool for Schistosoma mansoni infection in Ethiopian schoolchildren. J Trop Med Hyg 95: 52-56.

Engels D, Sinzinkayo E, Gryseels B 1996. Day-to-day egg count fluctuation in Schistosoma mansoni and its operational implications. Amer J Trop Med Hyg 54: 319-324.

Ferreira CS, Carvalho ME 1982. Padronização de uso de papel-filtro como suporte de material para reações sorológicas. Rev Bras Malariol 34: 82-86.

Hakangard C, Deelder AM, Gabone RM, Nilsson LA, Ouchterlony O 1996. A comparative study on specific antibodies and circulating antigen (CAA) in serum; and parasitological findings for diagnosis of schistosomiasis mansoni in an endemic area in Tanzania. Acta Trop 61: 213-222.

Hoshino-Shimizu S, Camargo MC, Kawada HYK, Silva LC, Dias LCS 1996. Aspectos sorológicos e soroepidemiológico da esquistossomose mansônica, p. 67-89. In FA Reis, I Faria, N Katz (eds), Modernos Conhecimentos sobre Esquistossomose mansônica, Anais da Academia Mineira de Medicina.

Idris MA, Ruppel A, Numrich P, Eschlbeck A, Shaban MAA, Diesfeld HJ 1994. Schistosomiasis in the southern region of Oman: vector snail and serological identification of patients in several locations. $J$ Trop Med Hyg 97: 205-210.

Kanamura HY, Dias LCS, Silva RM, Glasser CM, Patucci RMJ, Vellosa SAG, Antunes JLF 1998. A comparative epidemiologic study of specific antibodies (IgM and $\operatorname{IgA}$ ) and parasitological findings in an endemic area of low transmission of Schistosoma mansoni. Rev Inst Med Trop São Paulo 40: 85-91.

Kanamura HY, Silva RM, Rabello ALT, Rocha RS, Katz N 1991. Anticorpos séricos IgA no diagnóstico da fase aguda da esquistossomose mansoni humana. Rev Inst Adolfo Lutz 51: 101-104.

Katz N, Chaves A, Pellegrino J 1972. A simple device for quantitative stool thick-smear technique in schistosomiasis mansoni. Rev Inst Med Trop São Paulo 14: 397-400.

Kawazoe U, Hoshino-Shimizu S, Correa NS, Sila LC, Pinto ACM, Camargo ME 1981. An immunoepidemiological study of schistosomiasis in Paraiba's Valley, São Paulo, Brazil. Rev Inst Med Trop São Paulo 23: 36-40.

Lima DMC, Abrantes-Lemos CP, Hoshino-Shimizu S, Valli LPC, Kanamura HY, Silva LC, Vellosa SAG 1996. Imunodiagnóstico da esquistossomose mansônica com baixa carga parasitária. Rev Soc Bras Med Trop 29: 145-152.

Lima VLC de 1993. Esquistossomosse no Município de Campinas, PhD Thesis, Faculdade de Ciências Médicas, Unicamp, Campinas, SP. 217 pp.

Marçal Jr O, Patucci RMJ, Dias LCS 1991. Schistosomiasis mansoni in an area of low transmission. I. Impact of control measures. Rev Inst Med Trop São Paulo 33: 83-90.

Noya BA, Spencer I, Noya O 1992. Pre and post-treatment immunodiagnostic evaluation in human schistosomiasis. Mem Inst Oswaldo Cruz 87 (Suppl. IV): 271-276.

Noya O, Losada S, Alarcon de Noya B, Gonzalez S, Hermoso T, Balzan C, Cesari M 1995. Effect of chemotherapy on immune response to egg antigens of Schistosoma mansoni in chronically infected children from areas of low transmission. Parasitol Immunol 17: 111-117.

Silva LJ 1983. Sobre a antigüidade de alguns focos de esquistossomose do Estado de São Paulo. Rev bras Malariol D trop 35: 73-78.

Silva LJ 1992. A Esquistossomose Mansônica no Estado de São Paulo: Origens, Distribuição e Controle, Thesis, Faculdade de Ciências Médicas, Unicamp, Campinas, 140 pp.

Silva RM, Silva MIPG, Vellosa SAG, Kanamura HY 1992. Pesquisa de anticorpos IgM contra tubo digestivo do verme para o diagnóstico da esquistossomose mansônica. Rev bras Pat Clin 28: 39-42.

Sucen - Superintendência de Controle de Endemias 1982. Situação da esquistossomose no Estado de São Paulo. II Encontro sobre esquistossmose. São Paulo, Imprensa Oficial do Estado. [Relatório]. 82 pp. 
Immunofluorescence Test on Schistosoma mansoni • Virgília LC Lima et al. 